\title{
Hubungan antara hs-CRP, Adiponektin, Fetuin A terhadap Resistensi Insulin pada Pria Dewasa Muda dengan Obesitas Sentral
}

\author{
Tulus Amudi, ${ }^{1}$ Karel Pandelaki, ${ }^{2}$ Stella Palar ${ }^{2}$
}

\author{
${ }^{1}$ Program Pendidikan Dokter Spesialis Bagian Ilmu Penyakit Dalam Fakultas Kedokteran \\ Universitas Sam Ratulangi, Manado, Sulawesi Utara, Indonesia \\ ${ }^{2}$ Bagian Ilmu Penyakit Dalam Fakultas Kedokteran Universitas Sam Ratulangi - RSUP Prof. \\ Dr. R. D. Kandou, Manado, Sulawesi Utara, Indonesia \\ Email: tulusamudi@gmail.com
}

\begin{abstract}
Obesity has quite a lot of risk factors for the incidence of metabolic diseases such as insulin resistance, diabetes mellitus, dyslipidemia, and metabolic syndrome. The accumulation of adipocytes causes the formation of chronic inflammatory mediators, and disrupts adipokine derived from adipocytes. These inflammatory mediators cause hepatocytes to secrete several types of proteins such as C-reactive protein and fetuin A into the blood circulation that are thought to cause insulin resistance in obesity cases. This study was aimed to determine the relationship among levels of hs-CRP, adiponectin, and fetuin A, and insulin resistance in adult male subjects with central obesity. This was an observational study with a cross sectional design. Subjects were young adult males with central obesity at Prof. Dr. R. D. Kandou Hospital, Manado. The results showed that 30 subjects had a mean hs-CRP level of $0.18 \mathrm{mg} / \mathrm{dL}( \pm 0.16)$ which was higher than normal value. There was a positive and significant correlation between hs-CRP and HOMA-IR ( $\mathrm{r}=0.380$, $\mathrm{p}<0.023$ ). There was a negative and insignificant correlation between adiponectin and Homa IR ( $\mathrm{r}$ $=-0.278, \mathrm{p}=0.136$ ), and there was no significant correlation between fetuin A and HOMA IR ( $\mathrm{r}$ $0.048, \mathrm{p}=0.801$ ). In conclusion, among young adult males with central obesity there was an increase in hs-CRP level above normal value and there was a significant relationship between increased hsCRP and insulin resistance
\end{abstract}

Keywords: fetuin-A, high sensitive C-reactive protein, adiponectin, HOMA-IR, central obesity

\begin{abstract}
Abstrak: Obesitas memiliki faktor risiko yang cukup banyak terhadap kejadian penyakit metabolik seperti resistensi insulin, diabetes melitus, dislipidemia, dan sindrom metabolik. Akumulasi adiposit menyebabkan terbentuknya mediator inflamasi kronik sehingga sintesis adipokin oleh adiposit terganggu. Mediator inflamasi tersebut juga menyebabkan hepatosit menyekresi beberapa jenis protein seperti C-reaktif protein dan fetuin A ke dalam sirkulasi darah yang diduga meyebabkan resistensi insulin pada kasus obesitas. Penelitian ini bertujuan untuk mengetahui hubungan antara kadar hs-CRP, adiponektin, dan fetuin A dengan resistensi insulin pada subjek pria dewasa dengan obesitas sentral. Jenis penelitian ialah observasional dengan desain potong lintang. Subyek penelitian ialah pria dewasa muda dengan obesitas sentral di RSUP Prof. Dr. R. D. Kandou Manado. Hasil penelitian mendapatkan 30 subyek dengan rerata kadar hs-CRP $0,18 \mathrm{mg} / \mathrm{dl}( \pm 0,16)$ lebih tinggi dari nilai normal. Terdapat hubungan korelasi positif dan bermakna antara hs-CRP dan HOMA-IR ( $\mathrm{r}=0,380, \mathrm{p}<0,023)$; hubungan korelasi negatif dan tidak bermakna antara adiponektin dan Homa IR $(r=-0,278, p=0,136)$; tidak didapatkan hubungan bermakna antara Fetuin A dengan HOMA IR ( $\mathrm{r}=-0.048$ dan $\mathrm{p}=0,801)$. Simpulan penelitian ini ialah pada pria dewasa muda dengan obesitas sentral terdapat peningkatan kadar hs-CRP melebihi nilai normal dan terdapat hubungan bermakna antara peningkatan hs-CRP dengan resistensi insulin.
\end{abstract}

Kata kunci: fetuin-A, high sensitive C-reactive protein, adiponectin, HOMA-IR, obesitas sentral 


\section{PENDAHULUAN}

Obesitas merupakan masalah kesehatan serius di seluruh negara di dunia. Obesitas sangat berpengaruh terhadap perkembangan penyakit metabolik seperti resisten insulin, diabetes melitus, hipertensi perlemakan hati non alkoholik, penyakit hati, dan polikistik ovarium. ${ }^{1}$ Obesitas didefinisikan secara fisiologis sebagai suatu kondisi akumulasi lemak yang berlebihan di jaringan adiposa, dimana lemak yang didistribusikan pada bagian perut dikenal sebagai obesitas sentral dan pada daerah gluteus sebagai obesitas perifer. ${ }^{2}$ Akumulasi lemak ini akan menyebabkan gangguan sekresi adipokin dari jaringan adipose dan terbentuknya mediator inflamasi kronik derajat rendah.

Akumulasi jaringan adiposa juga akan menyebabkan peningkatan ekspresi mediator inflamasi, seperti ekspresi TNF $\alpha$, IL-6, dan IL-1 $\beta$. Terbentuknya mediator inflamasi, khususnya IL-6 akan merangsang hepatosit untuk menyekresikan $C$-reactive protein (CRP). Efek dari ekspresi mediator inflamasi akan menyebabkan terjadinya resistensi insulin melalui sekresi pembentukan suppressor of cytokine signaling (SOCS) dan protein tyrosine phosphatase 1 $B$ (PTPB) yang kemudian akan menghambat jalur kaskade sinyal insulin dengan cara defosforilasi reseptor insulin, penghambatan proses fosforilasi insulin, dan degradasi reseptor insulin (IRS). ${ }^{3}$

Adiponektin yang disekresi oleh jaringan adiposa memiliki fungsi untuk meningkatkan sensitivitas insulin, menurunkan glukoneogenesis hepatik, dan meningkatkan penyerapan glukosa di jaringan dan otot. Sitokin ini memiliki sifat anti inflamasi yang memengaruhi jalur nuclear factor $(\mathrm{NF}-\mathrm{\kappa B})$ dan juga memengaruhi sensitivitas insulin di jaringan perifer. Reseptor pada adiponektin, (AdipoR1) yang terdapat di jaringan otot akan berikatan dengan globular-head-groupadiponectin(gAcrp30) dan mengaktifkan adenosine monophosphate kinase (AMPK) melalui jalur sinyal spesifik reseptor, kemudian akan menyebabkan oksidasi asam lemak dan meningkatkan penyerapan glukosa di sel. Sekresi adiponektin akan menurun pada seseorang dengan obesitas. Akumulasi adiposit membuat sekresi adiponektin menurun. Dengan menurunnya sekresi adiponektin maka akan meningkatkan risiko terjadinya resistensi insulin. ${ }^{3}$

Fetuin-A juga dikenal sebagai alpha-2Heremans-Schmid glycoprotein (AHSG) yaitu glikoprotein terfosforilasi yang merupakan bagian dari protein pengikat serum fetuin, terdiri dari tiga rantai oligosakarida O-linked dan dua $\mathrm{N}$-linked yang disintesis dan disekresikan oleh hepatosit. ${ }^{4}$ Fetuin A merupakan inhibitor endogen insulin melalui penghambatan di reseptor tirosin kinase di hati dan jaringan otot. Sekresi fetuin A meningkat pada keadaan dislipidemia, obesitas, dan perlemakan hati. ${ }^{5}$

\section{METODE PENELITIAN}

Penelitian ini dilakukan sejak bulan Agustus 2020 sampai dengan Oktober 2020 di RSUP Prof. Dr. R. D. Kandou Manado, Sulawesi Utara, Indonesia. Jenis penelitian ini ialah observasional dengan desain potong lintang terhadap subjek dengan obesitas sentral. Subyek penelitian ini ialah pria dewasa muda dengan obesitas sentral yang rawat jalan, bekerja, dan mengunjungi RSUP Prof. Dr. R. D. Kandou Manado dalam selang waktu Agustus 2020-Oktober 2020 yang memenuhi kriteria inklusi dan eksklusi penelitian. Kriteria inklusi ialah pria dengan lingkar pinggang (LP) $\geq 90 \mathrm{~cm}$, rentang usia 18-40 tahun, dan bersedia mengikuti penelitian dan menandatangani surat persetujuan (informed concent), sedangkan kriteria eksklusi ialah diabetes melitus tipe 2 (DMT2), hipertensi, penurunan fungsi ginjal dengan laju filtrasi glomerulus (LFG) $<60 \mathrm{ml} / \mathrm{menit} / 1.73 \mathrm{~m}^{2}$, perokok, dan penggunaan obat NSAID atau steroid.

Sebagai uji penanda biokimia ialah pemeriksaan kadar fetuin-A menggunakan kit Enzyme Linked Immuno Assay (ELISA) yang berasal dari Bio Epitope Diagnostics, San Diego, CA. Pemeriksaan adiponektin menggunakan kit ELISA EZHADP-61K, 
Millipore, St. Charles, Missouri, USA. Pemeriksaan hs-CRP dan HOMA-IR serta kadar fetuin A dan adiponektin dilakukan oleh Laboratorium Pramita Manado.

Data perolehan dianalisis dengan menggunakan program Statistical Package for Social Scienses (SPSS). Analisis statistik deskriptif dilakukan untuk melihat deskripsi variabel penelitian yaitu nilai minimum, maksimum, rerata, median dan simpang baku serta distribusi dari semua variabel. Untuk menilai hubungan variabel bebas dan variabel tergantung dilakukan uji korelasi Pearson atau Spearman sesuai dengan hasil pengujian normalitas data. Nilai $\mathrm{p}<0,05$ menunjukkan adanya perbedaan statistik yang bermakna. Hubungan sebab akibat antara variabel diuji dengan analisis regresi linear sederhana.

Penelitian ini telah disetujui oleh komite etik penelitian RSUP Prof. Dr. R. D. Kandou Manado dengan nomor register 099/EC/KEPK-KANDOU/X/2020.

\section{HASIL PENELITIAN}

Pada penelitian ini didapatkan 30 sampel pria dewasa muda dengan obesitas sentral (LP $\geq 90 \mathrm{~cm}$ ). Tabel 1 memperlihatkan distribusi berdasarkan pemeriksaan kadar hs-CRP terhadap 30 sampel yang ikut penelitian, didapatkan sebanyak 19 sampel $(63,3 \%)$ dengan kadar hs-CRP tinggi (>0,1 mg/dl) dan 11 sampel $(36.6 \%)$ dengan kadar hs-CRP normal $(<0,1 \mathrm{mg} / \mathrm{dl})$. Berdasarkan kadar adiponektin, didapatkan 2 dari total 30 sampel $(6,6 \%)$ memiliki kadar adiponektin rendah yaitu $<5000$ $\mathrm{ng} / \mathrm{ml}$ dan sebanyak 28 dari total 30 sampel $(93,3 \%)$ memiliki kadar adiponektin normal. Untuk kadar fetuin-A didapatkan 28 dari total 30 sampel $(93,3 \%)$ memiliki kadar fetuin-A $>300 \mu \mathrm{g} / \mathrm{ml}$ dan hanya 2 sampel dengan kadar fetuin-A normal (140$300 \mu \mathrm{g} / \mathrm{ml})$. Uji kenormalan data dalam penelitian ini menggunakan uji SaphiroWilk. Hasil uji menunjukkan bahwa nilai hs-CRP, HOMA-IR, dan fetuin A tidak menyebar normal dengan nilai $\mathrm{p}<0,05$ sedangkan nilai adiponektin menyebar normal dengan nilai $\mathrm{p}>0,05$.

Tabel 2 menampilkan hasil uji Spearman terhadap hubungan antar variabel penelitian. Hubungan antara hs-CRP dan HOMA-IR dianalisis dengan analisis regresi linear sederhana dan uji koefisien korelasi Spearman. Hasil analisis menunjukkan adanya hubungan korelasi positif $(\mathrm{r}=0.380)$ dan bermakna secara statistik antara hs-CRP dan HOMA-IR pada subjek dewasa muda dengan obesitas sentral $(\mathrm{p}=0.023)$. Hubungan antara adiponektin dan HOMA-IR dianalisis dengan uji korelasi Spearman.

Tabel 1. Karakteristik subyek penelitian

\begin{tabular}{lccccc}
\hline \multicolumn{1}{c}{ Variabel } & N & Minimum & Maksimum & Rerata & $\begin{array}{c}\text { Simpang } \\
\text { Baku }\end{array}$ \\
\hline Usia & 30 & 28,00 & 36,00 & 31,70 & 2,61 \\
$\begin{array}{l}\text { HOMA-IR } \\
\text { Insulin } \\
(\mu \mathrm{IU} / \mathrm{ml})\end{array}$ & 30 & 0,76 & 7,43 & 2,43 & 1,59 \\
$\begin{array}{l}\text { GDP }(\mathrm{mg} / \mathrm{dl}) \\
\begin{array}{l}\text { Adiponektin } \\
(\mathrm{ng} / \mathrm{ml})\end{array}\end{array}$ & 30 & 4,20 & 155,50 & 20,00 & 35,67 \\
hs-CRP \\
$\begin{array}{l}\mathrm{mg} / \mathrm{dl})) \\
\text { Fetuin-A } \\
(\mu \mathrm{g} / \mathrm{ml})\end{array}$ & 30 & 60,00 & 94,00 & 80,13 & 9,13 \\
\hline
\end{tabular}

Keterangan: $\mathrm{n}=$ jumlah sampel penelitian; HOMA IR = homeostatic model assessment insulin resistance; $\mathrm{GDP}=$ gula darah puasa; hs-CRP $=$ high sensitivity $-C$ reactive protein 
Tabel 2. Hasil uji Spearman terhadap hubungan antar variabel penelitian

\begin{tabular}{llcccc}
\hline & & HOMA IR & Adiponektin & HSCRP & Fetuin A \\
\hline HOMA IR & Korelasi & 1,000 &,- 278 &, 380 &,- 048 \\
& Sig. (2-tailed) & - &, 136 &, 023 &, 801 \\
\multirow{5}{*}{ Adiponektin } & Korelasi &,- 278 & 1,000 &,$- 379^{*}$ &, $439^{*}$ \\
& Sig. (2-tailed) &, 136 & - &, 039 &, 015 \\
& N & 30 & 30 & 30 & 30 \\
hs-CRP & Korelasi &, 380 &,$- 379^{*}$ & 1,000 &,$- 681^{* *}$ \\
& Sig. (2-tailed) &, 023 &, 039 &. &, 000 \\
\multirow{5}{*}{ Fetuin A } & N & 30 & 30 & 30 & 30 \\
& Korelasi &,- 048 &, $439^{*}$ &,$- 681^{* *}$ & 1.000 \\
& Sig. (2-tailed) &, 801 &, 015 &, 000 &. \\
& N & 30 & 30 & 30 & 30 \\
\hline
\end{tabular}

*Correlation is significant at the 0.05 level (2-tailed).

Hasil analisis menunjukkan adanya korelasi negatif $(r=-0,278)$ dan tidak bermakna antara adiponektin dan HOMA-IR pada subjek dewasa muda dengan obesitas sentral $(p=0,136)$. Hubungan antara fetuin A dan HOMA IR dilakukan uji korelasi Spearman. Hasil analisis menunjukkan tidak terdapat hubungan antara fetuin-A dan HOMA-IR pada subjek dewasa muda dengan obesitas sentral $(\mathrm{p}=0,801)$.

\section{BAHASAN}

Penelitian ini bertujuan untuk mengetahui hubungan korelasi antara Hs-CRP, adiponektin, Fetuin-A terhadap resistensi insulin pada subyek pria dengan obesitas. Penelitian ini lebih ditujukan terhadap subyek pria untuk menghindari bias karena pengaruh hormonal. Pada obesitas terjadi penumpukan adiposit berlebihan yang dapat mengganggu kondisi kesehatan. Kelebihan makronutrien di jaringan adiposa menstimulasi pelepasan mediator inflamasi seperti tumor necrosis factor $\alpha(\mathrm{TNF}-\alpha)$ dan IL-6, namun menurunkan produksi adiponektin yang berfungsi sebagai antiinflamasi. Obesitas sangat berhubungan dengan berkembangnya inflamasi kronik derajat rendah yang terjadi di beberapa metabolisme jaringan tubuh seperti jaringan adiposa dan hati. Peningkatan kadar IL-6 merangsang hati untuk menyintesis dan mengeluarkan protein CRP. ${ }^{6}$ Efek ekspresi mediator inflamasi akan menyebabkan terjadinya resistensi insulin melalui sekresi pembentukan suppressor of cytokine signaling (SOCS) dan protein tyrosine phosphatase 1 $B$ (PTPB) yang kemudian akan menghambat jalur kaskade sinyal insulin dengan cara defosforilasi reseptor insulin, menghambat proses fosforilasi insulin, dan degradasi reseptor insulin (IRS). ${ }^{7}$

Dikatakan risiko rendah untuk berkembangnya penyakit kardiovaskular, resistensi insulin, dan penyakit metabolik lainnya, berdasarkan konsensus dari Centers for Disease Control and Prevention (CDC) pada tahun 2003 yaitu bila kadar hs-CRP $<0,1 \mathrm{mg} / \mathrm{dl}{ }^{8}$ Telah banyak studi potong lintang yang menunjukkan bahwa kadar hsCRP yang tinggi berkaitan dengan gangguan resistensi insulin. ${ }^{9}$ Hasil penelitian ini mendapatkan 19 sampel $(63,6 \%)$ memiliki kadar hs-CRP >0,1 mg/dl dan sebanyak 11 sampel (36,3\%) memiliki kadar hsCRP $<0,1 \mathrm{mg} / \mathrm{dl}$.

Hasil uji korelasi Spearman mendapatkan adanya hubungan korelasi positif dan bermakna antara hs-CRP dan HOMAIR pada subjek penelitian ( $\mathrm{r}=0,380$ dan $\mathrm{p}=0,023)$. Hasil uji ini menunjukkan bahwa semakin tinggi kadar hs-CRP akan cenderung terjadi peningkatan HOMA-IR. Mc Laughlin et $\mathrm{al}^{9}$ membandingkan kadar 
hs-CRP dan HOMA-IR pada subjek obesitas dan subjek non-obesitas dan mendapatkan hubungan antara peningkatan kadar hs-CRP dan HOMA-IR pada subjek dengan obesitas. Selain itu juga didapatkan penurunan kadar hs-CRP seiring dengan penurunan berat badan pada subjek penelitian tersebut. Hasil penelitian yang dilakukan oleh Yudkin et $\mathrm{al}^{10}$ menyatakan bahwa terdapat hubungan bermakna antara peningkatan hs-CRP terhadap resistensi insulin dan kejadian penyakit kardiovaskular. Penemuan dari hasil penelitian terkait peningkatan kadar hs-CRP pada subjek dengan obesitas mungkin dapat menjadi prediktor untuk mengidentifikasi seseorang yang sedang dalam keadaan prediabetes, termasuk dengan kejadian meningkatnya resistensi insulin pada subjek dengan obesitas. ${ }^{10}$

Adiponektin merupakan protein yang dihasilkan oleh adiposit yang berfungsi sebagai anti-inflamasi. Hal tersebut memberikan dampak positif berupa peningkatan sensitivitas insulin, penurunan glukoneogenesis hepatik dan peningkatan penyerapan glukosa di jaringan dan otot. Adiponektin menghambat phosphoenol pyruvate carboxykinase dan glucose-6-phosphatase sehingga menurunkan proses glukoneogenesis intrahepatik. ${ }^{11}$ Pada obesitas terjadi pembentukan mediator inflamasi yang mengakibatkan terjadinya penekanan sekresi adiponektin oleh adiposit. Rendahnya kadar adiponektin dikaitkan dengan kejadian penyakit metabolik seperti resistensi insulin, dislipidemia, DMT2, aterosklerosis, dan penyakit kanker kolorektal. Pada subjek dengan obesitas akan terjadi penurunan kadar adiponektin. ${ }^{12}$ Sebaliknya dengan modifikasi penurunan berat badan maka akan terjadi peningkatan kadar adiponektin dan dikaitkan dengan meningkatkan sensitivitas insulin. ${ }^{13}$ Pada penelitian ini didapatkan hanya 2 sampel $(6,6 \%)$ yang memiliki kadar adiponektin rendah, yaitu $<5000 \mathrm{ng} / \mathrm{ml}$. Penelitian yang dilakukan oleh Koska et a ${ }^{14}$ menyatakan bahwa kadar adiponektin tidak dipengaruhi oleh ketebalan lapisan lemak abdominal, melainkan peningkatan akumulasi lemak di hati yang memengaruhi rendahnya kadar adiponektin dalam serum.

Uji korelasi Spearman pada penelitian ini menunjukkan tidak terdapat hubungan bermakna antara kadar adiponektin dengan HOMA-IR pada subjek pria dewasa muda dengan obesitas sentral ( $\mathrm{r}=-0,278$ dan $\mathrm{p}=0,136)$. Hasil ini menunjukkan makin tinggi kadar adiponektin akan cenderung makin rendah HOMA-IR. Adiponektin menunjukan sifat anti-inflamasi dan meningkatkan sensitivitas insulin, sehingga kadar adiponektin memengaruhi kejadian penyakit metabolik. Novianti et $\mathrm{al}^{15}$ meneliti hubungan antara adiponektin dengan resistensi insulin pada subjek obesitas dan mendapatkan hasil korelasi negatif dan tidak bermakna $(\mathrm{r}=-0,167$ dan $\mathrm{p}=0,290$ ). Hubungan negatif antara adiponektin makin kuat dengan terjadinya penebalan lemak pada jaringan hati dan diikuti oleh penebalan lemak viseral, dibandingkan dengan penebalan lemak subkutan yang memiliki pengaruh yang sedikit untuk memengaruhi kadar adiponektin dalam tubuh. Kadar adiponektin dalam sirkulasi darah sangat menurun pada pasien dengan DMT2 dibandingkan pada pasien non diabetes. ${ }^{16}$ Penelitian ini dilakukan pada subjek non-diabetes sehingga membutuhkan penelitian lanjutan dengan membandingkan kadar adiponektin pada subjek dengan DMTT2 dengan subjek nondiabetes, dan dibutuhkan evaluasi untuk memeriksa ketebalan lemak dijaringan hati.

Fetuin-A adalah suatu glikoprotein dalam plasma yang dibentuk di hati dan dapat membawa asam lemak bebas ke dalam peredaran darah sistemik. Fetuin A ini memiliki sifat paradoks fungsional yang melekat pada kemampuan uniknya untuk berinteraksi dengan banyak reseptor yang dapat mengatur kegiatan utama yang terkait dengan kesehatan manusia dan penyakit. Fetuin A dikaitkan sebagai inhibitor sistemik dari kalsifikasi ektopik, tetapi sekaligus juga berperan penting pada suatu kondisi metabolik seperti sensitivitas insulin, toleransi glukosa, metabolisme lipid, serta protein pro-dan anti-inflamasi. ${ }^{17,18}$ Fetuin A ialah inhibitor reseptor tirosin kinase yang 
menyebabkan terjadinya resistensi insulin. Ekspresi fetuin A yang meningkat terbukti menyebabkan terjadinya akumulasi lemak berlebihan, terganggunya toleransi glukosa, dan peningkatan mediator inflamasi

Hasil uji korelasi Spearman pada penelitian ini menunjukkan bahwa tidak terdapat hubungan bermakna antara kadar fetuin-A dengan HOMA-IR pada subjek pria dewasa muda dengan obesitas sentral ( $\mathrm{r}=-0,048$ dan $\mathrm{p}=0,801$ ). Studi kohort yang dilakukan oleh Rametta et al ${ }^{19}$ menyatakan bahwa kadar fetuin-A meningkat bermakna pada subjek dengan non-alcoholic fatty liver disease(NAFLD) dan pada subjek dengan DMT2 atau pada subjek dengan toleransi glukosa terganggu dibandingkan dengan subjek non diabetes. Pada penelitian tersebut juga dijelaskan bahwa semakin berat derajat steatosis seseorang, maka akan terjadi peningkatan kadar fetuin-A secara bermakna. Dibutuhkan penelitian lanjut untuk membandingkan kadar fetuinA pada subjek obesitas diabetes dengan subjek obesitas tanpa diabetes.

\section{SIMPULAN}

Pada pria dewasa muda dengan obesitas sentral didapatkan korelasi positif dan bermakna antara kadar hs-CRP dan HOMA-IR serta korelasi negatif dan tidak bermakna antara adiponektin dan HOMAIR, namun tidak terdapat hubungan bermakna antara kadar fetuin-A dengan HOMA-IR.

Perlu dilakukan penelitian lanjutan dengan membandingkan variabel proinflamasi pada subjek obesitas dengan perlemakan hati dan subjek obesitas tanpa perlemakan hati. Pemeriksaan kadar hsCRP disarankan sebagai pemeriksaan rutin pasien dengan resiko resistensi insulin dan penyakit kardiovaskular.

\section{Konflik Kepentingan}

Penulis menyatakan tidak terdapat konflik kepentingan dalam studi ini.

\section{DAFTAR PUSTAKA}

1. Uyar, Ozata G, Sanlier N. Association of adipokines and insulin, which have a role in obesity, with colorectal cancer. Eurasian J Med. 2019;23(4):190-4.

2. Adams JMF. Obesitas. Pengertian dan kriteria diagnosis. In: Adam JMF, editor. Obesitas dan Sindroma metabolik. Bandung: FG publishing, 2006.

3. Trepanowski JF, Mey J, Varady KA. Fetuin-A: a novel link between obesity and related complications. Int $\mathbf{J}$ Obes (Lond). 2015;39(5):734-41.

4. Lim P, Moutereau S, Simon T, Gallet R, Probst $\mathrm{V}$, Ferrieres $\mathrm{J}$, et al. Usefulness of fetuin-A and C-reactive protein concentrations for prediction of outcome in acute coronary syndromes (from the French Registry of Acute ST-elevation non-ST-elevation myocardial infarction [FAST-MI]). Am J Cardiol. 2013; 111(1):31-7

5. Jensen MK, Bartz TM, Mukamal KJ, Djoussé L, Kizer JR, Tracy RP, et al. Fetuin-A, type 2 diabetes, and risk of cardiovascular disease in older adults: the cardiovascular health study. Diab Care. 2013;36(5):1222-8.

6. Griffin GE, Sissons JGP, Chiodoni PL, Mitchell DM. Disease due to infection. J Wound Care. 1999;11(6):205-9.

7. Ellulu MS, Patimah I, Khaza'ai, Rahmat A, Abed Y. Obesity and inflammation: The linking mechanism and the complications. Arch Med Sci. 2017;13(4):85163.

8. Pearson TA, Mensah GA, Alexander RW, Anderson JL, Cannonlll RO, Criqui M, et al. Markers of inflammation and cardiovascular disease: application to clinical and public health practice: a statement for healthcare professionals from the Centers for Disease Control and Prevention and the American Heart Association. Circulation 2003;107(3): 499-511.

9. McLaughlin T, Abbasi F, Lamendola C, Liang L, Reaven G, Schaaf P, et al. Differentiation between obesity and insulin resistance in the association with $\mathrm{C}$ reactive protein. Circulation. 2002;106 (23):2908-12.

10. Yudkin JS, Stehouwer CD, Emeis JJ, Coppack SW. C reactive protein in healthy subjects: associations with obesity, insulin resistance, and endothelial dysfunction: a potential role for cytokines originating from adipose tissue? 
Arterioscler Thromb Vasc Biol. 1999; 19(4):972-8.

11. Matsuda M, Shimomura I, Sata M, Arita Y, Nishida M, Maeda N, et al. Role of adiponectin in preventing vascular stenosis. The missing link of adipovascular axis. J Biol Chem. 2002;277 (40):37487-91.

12. Li S, Shin HJ, Ding EL, VanDam RM. Adiponectin levels and risk of type 2 diabetes: a systematic review and metaanalysis. JAMA. 2009; 302(2):179-88.

13. Baratta R, Amato S, Degano C, Farina MG, Patan_EG, Vigneri R. Adiponectin relationship with lipid metabolism is independent of body fat mass: evidence from both cross-sectional and intervention studies. J Clin Endocrinol Metab 2004;89(6):2665-71.

14. Koska J, Stefan N, Permana PA, Weyer C, Sonoda M, Bogardus $\mathrm{C}$, et al. Increased fat accumulation in liver may link insulin resistance with subcutaneous abdominal adipocyte enlargement, visceral adiposity, and hypoadiponectinemia in obese individuals. Am J Clin Nutr. 2008;87(2):295-302.

15. Novianti I, Wijaya A, Donosepoetro M. The relationship of fetuin-A, adiponectin, retinol binding protein-4 (RBP-4) and high sensitivity C-reactive protein (hsCRP) with insulin resistance (HOMA-IR) in obese non diabetic men. The Indonesian Biomedical Journal. 2012;4(1):17.

16. Kadowaki T, Yamauchi T, Kubota N, Hara $\mathrm{K}$, Ueki K, Tobe K. Adiponectin and adiponectin receptors in insulin resistance, diabetes, and the metabolic syndrome. J Clin Invest. 2006; 116(7): 1784-92.

17. Naito C, Hashimoto M, Watanabe K, Shirai R, Takahashi Y, Kojima M, et al. Facilitatory effects of fetuin-A on atherosclerosis. Atherosclerosis. 2016;246:344-51.

18. Sinhu S, Nadeem A, Rasheed A. Fetuin-A (AHSG) in metabolic and inflammatory diseases: a foe or a friend. Diabetes Obes Int J 2016;1(5):1-5.

19. Rametta R, Ruscica M, Dongiovanni $P$, Macchi C, Fracanzani AL. Hepatic steatosis and PNPLA3 I148M variant are associated with serum fetuin-A independently of insulin resistance. Eur J Clin Invest.2014;44(7):627-33. 